$\mathbb{T}$ Periodica Polytechnica

Social and Management

Sciences

23(1), pp. 7-14, 2015

DOI: $10.3311 /$ PPso. 7993

Creative Commons Attribution (i)

RESEARCH ARTICLE

\section{Impact of FDI on Economic Growth: Evidence from V4 Countries}

\author{
Elena Fifeková ${ }^{1}$ Edita Nemcová ${ }^{*}$
}

Received 29 August 2014; accepted 19 February 2015

\begin{abstract}
There is no way to adequately evaluate the economic development of the V4 countries over recent decades without taking into account the role played in it by foreign direct investment (FDI). Albeit the exact gains obtained from FDI are difficult to measure, their benefitial developmental impact has been evidenced by both the ensuing accelerated structural adaptation and higher levels of technological performance achieved across the V4 countries. FDI has ameliorated the areas of total factor productivity growth and export performance, rendering as well the market environment of the economies observed much more regular. FDI as a vehicle of acceleration of economic growth has contributed to the narrowing of the performance gap between the V4 grouping and the "old" EU member states. The first part of the article is, therefore, focused on the creation of conditions making for FDI inflow to the V4 countries. At the beginning of the economic transition, the FDI inflow to the V4 economies was predominantly dependent on their ability to secure favourable business environment and conditions required for the free movement of international capital.The second part of the paper seeks to compare FDI inflows to the V4 countries during the pre-and post-crisis periods. The upward impact of FDI stock on the economic growth throughout the V4 countries is then estimated by means of a growth accounting method. Lastly, we address the relationship between the technological level and absorptive capacity of the economies under scrutiny, with an eye to the potential impact of FDI on innovationrelated performance growth.
\end{abstract}

\section{Keywords}

foreign direct investment, economic growth, V4 countries, technology gap

\footnotetext{
${ }^{1}$ Institute for Forecasting, Slovak Academy of Sciences,

Šancová 56, 81105 Bratislava, Slovak Republic

* Corresponding author, e-mail: progedit@avba.sk
}

\section{Introduction}

Views and opinions on the impact of foreign direct investment on economic growth vary. Some authors maintain that the positive effects of FDI tend to benefit rather the countries of its origin than the host countries. They assume that it is exactly because of the inflow of FDI that the host economies may suffer a decline in innovation capabilities or the crowding out of local firms and local investment (Van Pottelsberghe and Lichtenberg, 2001; Nachum et al., 2000; Mišun and Tomšík, 2002; Kosová, 2010). Incoming FDIs may also cause the so called dual economy structure with high dependence on foreign capital in less developed countries (Jensen, 2006).

Overall, however, it is reasonable to claim that FDI has an important role to play in terms of the influence of individual factors on the performance of particular economies, above all, the transition countries of Central Europe (Damijan et al, 2013; Martin and Vinkler, 2009; Yang, 2008). The need for extensive restructuring on one hand, and the shortage of national capital stock on the other made the demand for investment in the individual V4 economies far exceed the possibilities given by respective national stocks, thus putting pressure on foreign funds. At the same time, the significantly lower technology performance of the countries observed and the necessity of narrowing the gap brought pressure to bear on FDI-assisted technology transfer (Barrell and Holland, 2000, Simurina, 2006). The importance of FDI to the countries of the former eastern block also went up in connection with a new model of economic growth that turned out to be substantially different from the one that was characteristic for most old EU member states in the latter half of the 20th century.

\section{Economic growth in the V4 countries}

The pre-crisis economic growth achieved across the V4 countries appeared to be sustainable and seemed to make sufficient room for quick catching-up with the economic level of the old member states (Fifeková, 2013). Both the possibility of utilising the EU funds and the commitment to meet the convergence criteria spurred vigorous pro-growth impulses. From the perspective of investors the countries were considered to 
be safe as the need for fulfillment of the convergence criteria created prerequisites for good return on investment (Sass and Fifekova, 2011). At the same time the improvement of the conditions for mobility of production factors made room for increased capital flows into the region.

The long-term economic growth rate across the V4 countries in 1995 -2013 was 1.7 percentage points higher than that of the EU15 member states (Table 1), which resulted mainly from the above-average real GDP growth rate in Poland and Slovakia. The indicated differences between the V4 and old member states became particularly noticeable in the pre-crisis period when the V4 countries' growth dynamism increased, especially immediately after their EU accession.

Table 1 Long-run economic growth (in \% based on 2005 prices)

\begin{tabular}{cccc}
\hline & $\mathbf{1 9 9 5 - 2 0 1 3}$ & $\mathbf{1 9 9 5 - 2 0 0 8}$ & $\mathbf{2 0 0 9 - 2 0 1 3}$ \\
\hline EU27 & 1,55 & 2,20 & 0,67 \\
EU15 & 1,45 & 2,10 & 0,61 \\
V4 & 3,16 & 3,84 & 1,64 \\
Czech & 2,25 & 3,23 & 0,46 \\
Republic & 1,85 & 2,88 & 0,41 \\
Hungary & 3,89 & 4,32 & 2,38 \\
Poland & 3,71 & 4,70 & 2,02 \\
Slovakia & & & \\
\hline
\end{tabular}

Source: Eurostat, own calculation

A higher growth rate of the V4 countries was the consequence of both their lower economic power (Fig. 1) and the influence of many growth-inducing factors, above all, the technological catching-up and the restructuring of the economies in question.

Nevertheless, the highly positive pre-crisis output gap, typical of nearly all the V4 countries, suggested that the acceleration of their economic growth indicated a rather cyclical character, being hence hardly sustainable (the overheating of the economies was primarily reflected by the deteriorated parameters of the external economic balance) (Fifeková et al., 2013).

The economic growth of the V4 countries (except for Poland) was halted by the crisis of 2009. At present, all the economies concerned find themselves under the level of their long-term development trend, with the most significant difference between their long-run and current trend being in the Czech Republic and Hungary. The crisis has reversed the relationship between the real and potential product with all the countries in question presently being below the level of their production capabilities. Despite the improving economic situation in the post-crisis period, the individual countries are having difficulties closing the indicated negative output gap.

The ongoing slowdown of the economic growth within EU shifts the hitherto overwhelmingly optimistic expectations of relatively rapid economic catching-up of the V4 countries

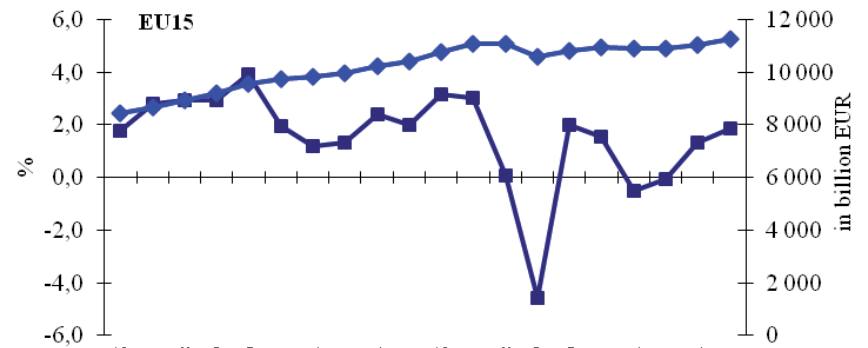

品 $\rightarrow$ year-on-year GDP growth rate (left axis) $\multimap$ gross domestic product (right axis)

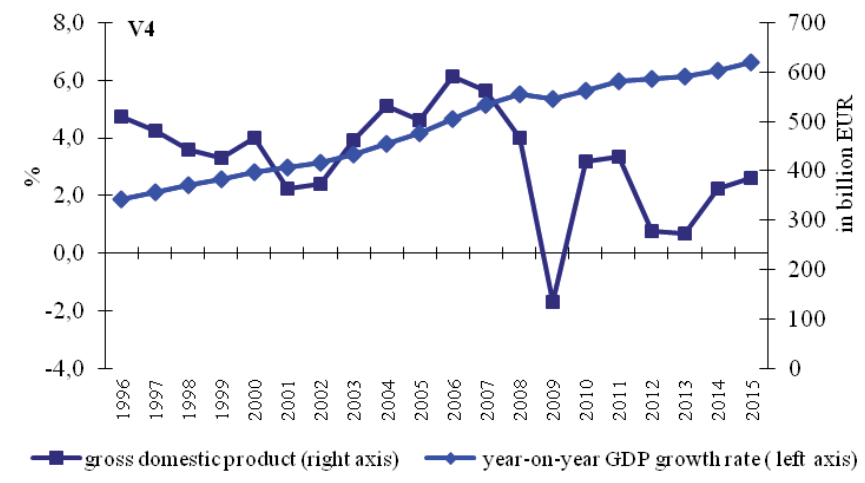

Fig. 1 Real GDP level and growth (2005 prices)

Source: European Commission(Ameco), own calculation

Table 2 Development of the output gap (in $\%$ of potential product, at constant 2005 prices)

\begin{tabular}{cccc}
\hline & $\mathbf{1 9 9 9 - 2 0 0 3}$ & $\mathbf{2 0 0 4 - 2 0 0 8}$ & $\mathbf{2 0 0 9 - 2 0 1 3}$ \\
\hline EU27 & 0,92 & 1,41 & $-2,41$ \\
EU15 & 1,01 & 1,31 & $-2,48$ \\
Czech & $-0,60$ & 3,99 & $-1,64$ \\
Republic & 0,61 & 3,64 & $-3,53$ \\
Hungary & $-0,52$ & 0,91 & $-0,05$ \\
Poland & $-1,73$ & 3,46 & $-1,86$ \\
Slovakia & Sourc: Eun
\end{tabular}

Source: European Commission (Ameco), own calculations

with the old member states (Kotian, 2014) towards more cautious and even pessimistic ones. The principal threat to the V4 countries is posed by the slowdown of growth dynamism within the EU15, which may well lead to significant decline in the economic growth due to the weakening of the pro-growth influence exerted by the net exports (it is the EU15 member states that happen to be the primary territory for the V4 countries' exports).

The extent to which the V4 countries will be able to deliver conditions for narrowing the performance gap within a reasonably short time-period depends, first and foremost, on their effort to create prerequisites for sustainable economic growth, which should outrun that of the EU15 countries at least by one percentage point. To meet this ambition, it is important that the catching-up countries ensure the permanence of pro-growth 


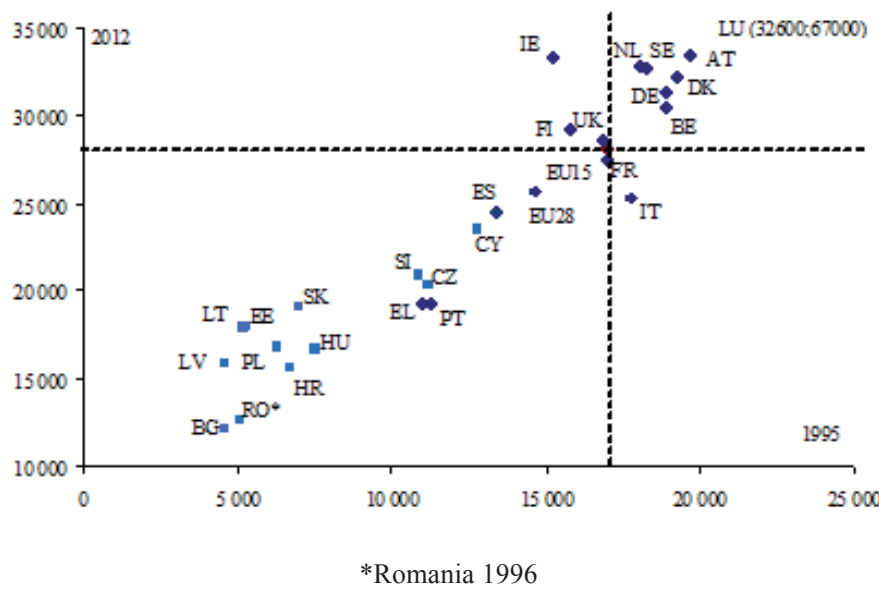

Fig. 2 Per capita GDP across the EU countries (in PPS). Source: Eurostat

action on the part of individual factors contributing to GDP growth. The crucial question therefore remains to what extent in the near future EU countries manage to return to their precrisis growth trajectory.

The following parts of the article will analyse the role foreign direct investment might have played in the rapid pre-crisis growth and its potential importance in the post-crisis development of the V4 countries.

\section{Impact of foreign direct investment on the V4 countries' economic growth}

\subsection{Location determinants and development of Foreign direct investment in the V4 countries}

The FDI inflow and stock within the V4 countries was affected mainly by the states' ability to create favourable environment for foreign investors as well as by the promptness with which particular V4 countries had complied during the pre-accession period with the requirement of openess to international capital movement (Kinoshita and Kampos, 2002). Gradual liberalisation of the individual balance of payments accounts therefore became a part of establishing market standards. The liberalisation progress depended on initial conditions and the nature of the transformation process in each country.

The starting point for the liberalisation of capital movement was convertibility of balance of payments current account, which was a requirement for the IMF membership and, simultaneously, was being endorsed by association agreements between the individual economies and the EU. After reaching the convertibility on the balance of payments current account in the years 1994-1996, it was primarily the ambition to enter the EU that became a strong stimulus to accelerate the process of capital movement liberalisation across the V4 countries. Since free movement of capital constitutes the fundamental prerequisite for the functioning of single market within an integration block, the requirement of institutional provisions for the liberalisation of capital/financial account was for the V4 countries essential condition of their accession processes. ${ }^{1}$ Under Article
56 of the Treaty on European Union, the European Commission, in conjuction with the individual V4 countries, worked out a timetable of gradual liberalisation of capital flows. In terms of the pace of de-regulating capital movement, the process in each V4 country was very different. While the Czech Republic had been de-regulating capital transactions since as early as 1995, Hungary, Poland, and Slovakia were liberalising capital transactions gradually and well until their EU accession. When the association agreements came in force, the movement of foreign direct investement was liberalised. Also another factor responsible for acceleratiing the de-regulation of capital movement was the V4 countries' effort to become members of OECD.

A decisive role in the volumes of FDI inflow to the V4 countries was played by the approach adopted to the privatisation of state assets (Johnson, 2006) (eg while Hungary favoured privatisation via direct sales to foreign investors, Slovakia ${ }^{2}$ preferred an approach of leaving former state enterprises in the hands of domestic subjects). The scale of investment incentives offered to foreign investors by individual countries also played an important part in attracting FDIs (Drahokoupil, 2008).

The inclusion of the V4 countries among the so called accessing states, but especially the EU accession itself gave a boost to the FDI inflows into the aforementioned economies mainly due to the increased investors 'confidence in the presence of a standard market environment (Kalotay, 2004). In terms of the development of FDI inflows to the countries within the EU, there has been a direction-shift in favour of the newly admitted member states, which is evident both in the total inflow and above all in the FDI inflow from the old member states (see Graph 2) to the new ones.

Throughout the whole period analysed, FDI inflow as a percentage of GDP was significantly higher in the V4 countries (see Graph 2) than in the old member states, with the extent of the inflow within the V4 countries being quite differentiated over time and primarily dependent on the promptness of economic reforms implemented in each country. In the context of the V4 countries as a whole, the FDI inflow was at its highest point in the period before accession to the EU, mainly due to a massive increase in FDI inflow to Slovakia and the Czech Republic.

Following 2009, a considerable drop in FDI inflow occurred across all the V4 countries, in absolute terms the decrease being the steepest (by 3.2 times) in Slovakia and the mildest (by 1.2 times) in Hungary. In all the V4 countries as a whole, the absolute FDI inflow suffered a 1.7 -fold decline.

Compared internationally, the V4 countries' relative position in terms of their FDI stock (i.e. the FDI stock as a percentage

1 Transition measures allowed the retention of certain restrictions (for instance, in the area of acquisition of agricultural land and forests as well as real property) even following the countries' EU accession.

2 In Slovakia, the law on strategic enterprises eliminated the possibility for non-nationals to privatise strategic enterprises. 


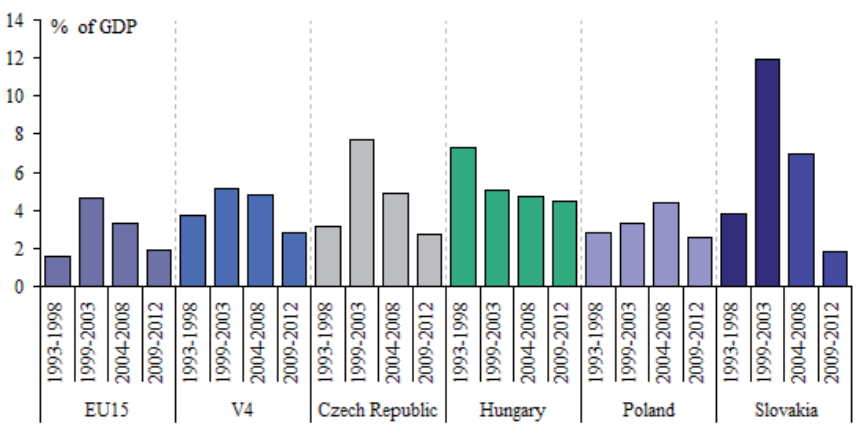

Fig. 3 FDI inflow to V4 countries (percentage of GDP) Source: FDI Statistics Database. UNCTAD, own calculation

of GDP) is good (see Graph 3) as it currently exceeds the relative FDI stocks of the old member states by over 12 percentual points. As a percentage of GDP, Hungary has the largest FDI stock ( $81.7 \%$ ), followed by that of the Czech Republic (69.6 $\%)$ and Slovakia that reaches the level of $60.85 \%$.

In contrast to economically more advanced countries, the so called investment circle in the V4 countries does not close. The investment position of the countries in terms of FDI is highly negative, most often nearing the incoming FDI stock in their respective economies. The above suggests that these countries are primarily recipients of incoming FDI, while the stock of outgoing FDI of the indicated countries is minimal.

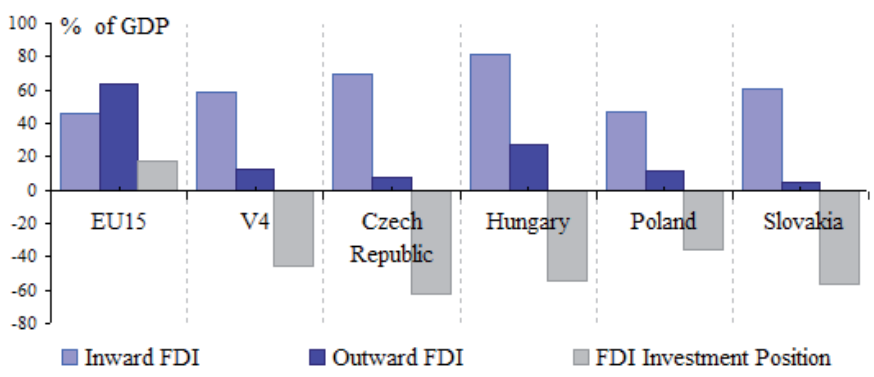

Fig. 4 Stock and investment position of FDI across selected EU member states (2012, \% of GDP) Source: FDI Statistics Database. UNCTAD, own calculation

The overall increased level of FDI inflow to the new member states has been significantly affected by the relocation of production activities from the old member states (Dachs et al, 2012), which conditioned the high level of dynamism of the V4 countries' economic growth that outran those of the old member states. Foreign investors from the old EU member states relocated part of their activities primarily in manufacturing industry to the new member states (Eurofond, 2013). This transfer of jobs and production to other, mostly less advanced countries, has been a frequent subject of many debates (Hunya and Geishecker, 2005). The debates have also been fuelled by the fact that the relocation affected all sectors, not just the traditional ones requiring low-skilled workforce. Industries depending on high-skilled labour have been relocated as well (Hardy, 2011).

Looking at this matter rationally, relocation and de-industrialisation (reducing the share of manufacturing employment in total employment) are tangible and visible effects of the structural adaptation process, whose main driving forces involve global economic integration, international competition and technological progress. So rather than focusing on short-term relocation effects, it would be a better idea to judge relocation in the proposed, broader perspective. Viewed from such an angle, relocation need not be necessarily perceived negatively, as vast majority of its definitions imply. Focusing on short-term effects (e.g., workforce layoffs) might lead to ignoring such mediumand long-term effects linked to the process of structural adaptation as motivation behind individual firms' decisions to relocate their activities, such as cost saving, improving access to foreign markets and strategic capital, human capital included (Dicken, 2011; Refslund and Andersen, 2014; Stehrer et al., 2012).

The relocation of industries from the old $\mathrm{EU}$ members to the newly accepted member states can be a reliable and important alternative to its relocation to other parts of the world. This trend has most notably manifested in the case of automotive industry, which gained a dominant position in the V4 countries (Fortwengel, 2011; Kaminski and Smarzynska, 2001). The above development, however, has also brought the risk of rendering a small open economy dependent on one dominant industry, which during the crisis proved as a real threat to these countries.

\subsection{Impacts of foreign direct investment in the V4 countries}

In general, FDI tend to be credited for their promotion of economic growth in the new member states (Kornecki, 2008), contribution to creation of new jobs, labour productivity growth, efficiency of resource allocation, increased competitiveness of economies and addressing regional disparities (Moura and Forte, 2010; Alfaro, 2003; Kaminski and Smarzynska, 2001; Gorg and Greenaway, 2004; Barrell and Pain, 1997). According to the estimates of the European Commission's study (2009), the accession of the new member states to the EU increased their economic growth in the years $2000-2008$ on average by $1.75 \%$, while an important factor of this impact (alongside the improvement in the quality of macroeconomic and institutional framework), the study suggests, was the increased productivity driven by FDI and FDI-facilitated technology tranfer.

Yet it is necessary to be aware of the fact that the high inflow of FDI to the V4 countries was often the consequence of privatisation of state-owned enterprises. ${ }^{4}$ That resulted in higher efficiency but did not resolve the issue of unemployment. The greenfield investments that increase the supply of jobs were many times low (Bacic, 2009). Another factor that

3 In Slovakia, for instance, the massive FDI inflow was conditioned by exactly such a reality. According to the data by the Slovak National Bank and the World Bank, the share of revenue from the privatisation of state-owned enterprises in FDI in the year 2000 accounted for over $46 \%$, in 2001 for almost $66 \%$, in 2002 nearly $82 \%$, in 2003 for $50 \%$, in 2004 over $44 \%$... in 2009 it exceeded $23 \%$ 
demystifies over-optimistic perception of FDI, is the generosity of investment incentives provided to attract FDI into the country (Iwasaki and Tokunaga, 2013; Cass, 2007). Provision of an investment incentive proceeds from the assumption that its benefit is going to be higher than the amount of FDI support provided by the government and at the same time also higher than the benefit that would be achieved by providing equal endorsement to domestic subjects. It is also assumed that such investment incentive might help sort out urgent problems of the economy, particularly in the area of regional disparities. The experience of the V4 countries shows that the bulk of FDI went to the regions with the highest GDP per capita and that new jobs created due to investment incentives did not reduce regional disparities in unemployment (incentives were often directed to the regions with lower unemployment rates) (Hardy et al, 2011). The thing is that FDI, in most cases, required skilled workforce, which happened to be available exactly in the regions with a lower unemployment rate. At the same time, the costs incurred by the creation of a new job with the help of investment incentives far exceeded the costs of workplaces emerging without such support.

FDI have significantly contributed to the restructuring of the V4 countries, but also increased considerably the economies' dependance on foreign investors (Galgóczi, 2009). Another risk associated with FDI is also the fact that large international companies tend to retain the most lucrative activities (such as R\&D, management, etc.) in their home countries. Sometimes activities benefitial to their home economies are clearly favoured

Table 3 FDI inflow to the V4 countries (\% of Gross Fixed Capital Formation)

\begin{tabular}{|c|c|c|c|c|c|c|c|c|}
\hline & 1996 & 1997 & 1998 & 1999 & 2000 & 2001 & 2002 & 2003 \\
\hline$E U 27$ & 6,8 & 8,4 & 15,5 & 27,1 & 40,1 & 22,3 & 17,1 & 12,8 \\
\hline Czech Republic & 6,8 & 7,3 & 20,3 & 36,7 & 29,4 & 30,8 & 39,1 & 8,2 \\
\hline Hungary & 32,9 & 40,7 & 30,1 & 28,7 & 24,5 & 31,6 & 19,3 & 11,4 \\
\hline Poland & 14,5 & 13,9 & 15,4 & 17,7 & 23,2 & 14,5 & 11,1 & 11,6 \\
\hline \multirow[t]{2}{*}{ Slovakia } & 5,5 & 3,2 & 8,8 & 7,1 & 51,5 & 37,6 & 87,1 & 36,0 \\
\hline & 2004 & 2005 & 2006 & 2007 & 2008 & 2009 & 2010 & 2011 \\
\hline$E U 27$ & 8,8 & 18,2 & 19,2 & 23,8 & 14,1 & 11,6 & 12,6 & 13,5 \\
\hline Czech Republic & 16,8 & 34,6 & 14,3 & 21,3 & 10,6 & 6,0 & 12,6 & 4,5 \\
\hline Hungary & 18,4 & 30,7 & 27,9 & 13,3 & 18,9 & 7,6 & 9,2 & 23,2 \\
\hline Poland & 28,1 & 18,6 & 29,2 & 25,7 & 12,6 & 14,2 & 14,9 & 18,1 \\
\hline Slovakia & 39,7 & 24,4 & 39,1 & 20,4 & 20,8 & 0,0 & 9,1 & 9,9 \\
\hline
\end{tabular}

A growth accounting method ${ }^{4}$, which enables the identification of the impact of capital stock, implies that the real product growth rate is conditioned by the growth rate of capital, labour and total factor productivity of progress (the specification of this method assumes constant returns to scale, diminishing returns from each input as well as positive and continuous elasticity of substitution between the inputs) ${ }^{5}$.

Table 4 Sources of economic growth (in \%, GDP and net stock of capital at constant 2005 prices)

\begin{tabular}{|c|c|c|c|c|c|c|c|c|c|c|c|c|}
\hline & \multicolumn{4}{|c|}{ 1999-2015 } & \multicolumn{4}{|c|}{ 2004-2008 } & \multicolumn{4}{|c|}{ 2009-2014 } \\
\hline & GDP & $\begin{array}{l}\text { capital } \\
\text { factor }\end{array}$ & $\begin{array}{l}\text { labour } \\
\text { factor }\end{array}$ & TFP & GDP & $\begin{array}{l}\text { capital } \\
\text { factor }\end{array}$ & $\begin{array}{l}\text { labour } \\
\text { factor }\end{array}$ & TFP & GDP & $\begin{array}{l}\text { capital } \\
\text { factor }\end{array}$ & $\begin{array}{l}\text { labour } \\
\text { factor }\end{array}$ & TFP \\
\hline EU 27 & 1,58 & 0,68 & 0,32 & 0,59 & 2,33 & 0,84 & 0,79 & 0,70 & 0,03 & 0,35 & $-0,26$ & $-0,06$ \\
\hline$V 4$ & 3,09 & 0,96 & 0,09 & 2,03 & 5,09 & 1,51 & 1,16 & 2,43 & 1,59 & 0,47 & 0,00 & 1,12 \\
\hline Czech Republic & 2,61 & 0,66 & 0,07 & 1,87 & 5,47 & 0,92 & 1,00 & 3,55 & $-0,9$ & 0,44 & $-0,23$ & $-0,30$ \\
\hline Hungary & 1,87 & 1,31 & 0,03 & 0,53 & 2,73 & 2,05 & $-0,19$ & 0,87 & $-0,54$ & 0,36 & $-0,05$ & $-0,85$ \\
\hline Poland & 3,64 & 2,20 & 0,02 & 1,42 & 5,42 & 2,22 & 1,40 & 1,80 & 2,63 & 2,41 & $-0,13$ & 0,35 \\
\hline Slovakia & 3,80 & 1,22 & 0,10 & 2,48 & 7,26 & 1,99 & 0,85 & 4,42 & 1,21 & 0,44 & $-0,10$ & 0,86 \\
\hline
\end{tabular}

In the case of labour and capital, weighted growth rate is used, the weights being labour and capital elasticity of product (an income share of labour and capital). Source: The European Commission (Ameco), Eurostat, GGDC, the authors' calculations.

4 The method of growth accounting in analysing the sources of economic growth is employed by the European Commission, OECD, the International Monetary Fund the World Bank, and the US Bureau of Labor Statistics.
5 Real GDP growth rate is the sum of the growth rate of the total factor productivity and the weighted sum of the labour and capital growth rate, where the weights are labour and capital elasticity of the product, e.i., an income share of labour and capital 
(e.g., taking firms back to the home countries). Equally, private FDI (e.g., in the banking sector) tend to feel obliged to follow the recommendations of authorities in their home countries, for example financial supervisory authorities (Gabrielová, 2013).

The FDI promotion often proceeds from the assumption that FDI tend to raise real GDP growth rate (Khawar, 2005), therefore, the higher the FDI inflow to an economy, the higher the economic growth the country achieves. This assumption, though, cannot be clearly confirmed by the V4 countries' experience, because the countries with the highest FDI inflows (Hungary and the Czech Republic) reached in the 90s lower economic growth than the V4 countries that received much lower FDI inflows (Poland and Slovakia). The impact of FDI on economic growth primarily manifests itself through the raised volume of total investment into the fixed capital of a given country (see Table 3), which is, in turn, reflected in the growth of capital stock that represents the essential source of economic growth.

As can be seen from Table 4, it was the weighted growth rate of capital and growth rate of total factor productivity that were exerting most influence on the economic growth during the whole period analysed. The weighted growth rate of labour affected the economic growth the least, actually dampening it in the post-crisis period.

In the years 2000-2013, the average annual growth rate of the net capital stock was 1.3 percentual points higher in the V4 countries than in the EU28 - mostly due to the growth of the net capital stock in Poland, where the real average growth rate reached $3.9 \%$, and in comparison with the year 2000 the net capital stock increased by $180 \%$. Following 2008, the year-onyear dynamism of the capital stock growth experienced a moderate decline across all of the observed countries. In Hungary and Slovakia ${ }^{6}$, the growth of the capital stock almost stopped as a consequence of the sluggish investment activities during the crisis period and in its aftermath.

The pro-growth influence of total factor productivity, which during the whole period was most pronounced in the Czech Republic and in Slovakia within the V4 countries, was also affected to a large extent by the presence of FDI in the region. In addition to technological transfer, FDI also brought to the V4 countries intangible assets in the form of know-how, managerial and marketing skills, innovation and knowledge capital, which ultimately promoted the growth of total factor productivity. Now, the impact of the total factor productivity on the growth of GDP was, similarly to other factors, very differentiated in time. The highest growth of total factor productivity was achieved in the years 2004-2008, while during the postcrisis period, in the Czech Republic and Hungary the total factor productivity growth and the real GDP growth decrease.

The extent to which FDI will positively affect the economic growth of the V4 countries depends, primarily, on shaping

6 In the year 2013 the capital stock growth in Slovakia was negative. economic environment which will be capable of not only absorbing the effects brought by FDI, but also developing them further. The current trend of decreasing FDI inflows to the V4 countries indicates that it is possible to survive in the fierce competition among government to attract FDIs only if the country offers stable macroeconomic and favourable business environment and it's absorption capacity in terms of technological readiness and innovation potential is continously rising. It is exactly the advancement of individual areas of an economy's absorption capacity (e.i., education system of a given country, creation of conditions for the establishment and development of country's own R\&D, quality of human capital and of business environment) that determines the extent to which that country is able to attract foreign investors, who will actually strengthen the country's own innovation potential - be it via transfer of technologies or through the entrance of FDI in the mode of a scientific research facility.

The existence of a relationship between the capacity of a host country to absorb the effects of technological transfer and the scale of the effects of such a transfer proves that a low technological absorption may hinder the emergence and growth of positive effects of FDI. In case that the technological transfer is not sufficiently supported by a host country's own innovative activity as well as by raising technological level of the economy and its transition to a qualitatively a higher level of competitiveness, the positive effect of the teachnology transfer may be relatively quickly exhausted. If the given economy lacks the adequate level of innovative potential, the country may find itself facing the situation, that after having exhausted all cost- and wage-related comparative advantages, FDI will relocate their economic activities to cheaper locations. At the same time, low domestic innovative activity, coupled with reliance on foreign sources of innovation, tend to pose, in a long-term perspective, considerable risks (for instance, it is not guaranteed that foreign capital will bring along cuttingedge technologies, or sufficiently encourage pro-innovation behavioral changes, or, that the scale of investment incentives will not undermine the fiscal stability of a given economy, etc.).

Comparative advantages which a country can gain from FDI inflow depend to a great extent on the position of foreign-controlled firms in the international value chain. This position is derived from the country's economic development level, its own innovative capabilities as well as the sophistication of technological and workforce skills-related inputs. The point is that countries with insufficient innovative level generally tend to become, as part of the fragmentation of the value chain, destinations for mainly production activities of an assembling nature characterised by a low level of value added. A low technological and innovation potential of an economy will result in a gradual relocation of lower innovative order technologies to the country. Therefore, neglect or underestimation of the importance of building a country's own research base poses 
a risk of not just entirely losing its innovative potential, but also gradually reducing its imitation capability to a large extent, regardless of the extent of the FDI presence.

\section{Conclusion}

The FDI inflow and stocks across the V4 countries were determined by the creation of conditions for FDI entry in the pre-accession period as well as by the EU accession itself. The FDI inflow depended largely on the promptness of implementation of economic reforms in each country, approach adopted to the privatisation of state assets and the scale of investment incentives offered, reaching its highest peak in the period preceding the EU accession. In terms of the FDI structure, the V4 countries attracted to a great extent privatisation investment, which in most cases improved production and allocation efficiency of economies, contributed to the strengthening of their competitiveness as well labour productivity at foreign-controlled enterprises - reducing, though, the possible pro-growth impact of labour factor on the economic growth. The impact of FDI on the economic growth manifested itself primarily in the increase of total investment volume in fixed capital of a given country and consequently in the rise of capital stock, which along with an increase in the total factor productivity had a significant influence on the real GDP growth rate across the V4 countries. At that, it needs be taken into consideration that a highly growth-inducing TFP (total factor productivity) impact on the economic growth in the pre-crisis period was intensified by FDI presence in the V4 countries as, in addition to technology transfer, FDI had also brought intangible assets in the form of know-how, managerial and marketing skills, innovation, and knowledge capital. The extent to which FDI will positively impact the economic growth of the V4 countries in the future depends, primarily, on creating economic environment which will be capable of not only absorbing the positive effects brought by FDI, but also developing them further. It is the absorption capacity and the technological and innovation potential which will determine the countries' ability to attract foreign investors and the scale of comparative advantages the economy will gain from the FDI inflow.

\section{Acknowledgement}

This paper was supported by grant VEGA No. 2/0010/14 „Institutional and technology change in the context of the European challenges“" along with grant VEGA No. 2/0160/13 „Financial stability and sustainability of Slovakia's economic growth under the conditions of global economy ".

\section{References}

Alfaro, L. (2003) Foreign Direct Investment and Growth: Does the Sector Matter? Harvard Business School. <http://www.51lunwen.org/ UploadFile/org20110130901063260/011013090106459.pdf>
Bačić, K., Račić, D., Ahec-Šonje, A. (2004) The effects of FDI on recipient countries in Central and Eastern Europe. Economic Trends and Economic Policy. 14 (100). 2004.

Barrell, R., Holland, D. (2000) Foreign Direct Investment and Enterprise Restructuring in Central Europe. Economics of Transition. 8 (2). pp. 477-504. DOI: 10.1111/1468-0351.00052

Barrell, R., Pain, N. (1997) Foreign direct investment, technological change, and economic growth within Europe. Economic Journal. 107. pp. 17701786 URL: http://www.jstor.org/stable/2957907

Casey, W. L. (2006) Foreign direct investment as an engine of economic development. Advances in Competitiveness Research. 14 (1).

Cass, F. (2007) Attracting FDI to transition countries: the use of incentives and promotion agencies. Transnational Corporations. 16 (2). pp. 77-122.

Damijan, J., Kostevc, Č., Rojec, M. (2008) Global Supply Chains at Work in Central and Eastern European Countries: Impact of FDI on export restructuring and productivity growth. Licos Discussion papers DP 332.

Dachs, B., Borowiecki, M., Kinkel, S., Schmall, T. C. (2012) The Offshoring of Production Activities in European Manufacturing. MPRA Paper No. 42973. AIT Austrian Institute of Technology.

Dicken, P. (2011) Global shift: Mapping the changing contours of the World economy. 6th ed. London: Sage.

Drahokoupil, J. (2008) The Investment-Promotion Machines: The Politics of Foreign Direct Investment Promotion in Central and Eastern Europe. Europe-Asia Studies. 60 (2). pp. 197-225.

DOI: $10.1080 / 09668130701820085$

Eurofound (2013) Monitoring and managing restructuring in the 21st century. Luxembourg: Publications Office of the European Union.

European commission (2009) Five years of an enlarged EU. Economic achievements and challenges. Economic and Financial Affairs. ISBN 978-92-79-11273-7.

Fifeková, E. et al. (2013) Ekonomický rast a jeho kvalita. (Economic Growth and Its Quality) Bratislava : Vydavatel'stvo EKONÓM. ISBN 978-80225-3807-7. (In Slovakian)

Fortwengel, J. (2011). Upgrading through Integration? The Case of the Central Eastern European Automotive Industry. Transcience Journal. 2 (1).

Gabrielová, H. (2013) Slabé stránky slovenskej ekonomiky. (Weaknesses of Slovak Economy) In: Pohl'ady na štruktúrne problémy slovenskej ekonomiky. (Insights on Structural Problems of Slovak Economy). Bratislava: VEDA, vydavatel'stvo SAV. ISBN 978-80-7144-216-5. (In Slovaklian)

Galgóczi, B. (2009) Boom and Bust in Central and Eastern Europe: Lessons on the Sustainability of an Externally Financed Growth Model. Journal of Contemporary European Research. 5 (4). pp. 614-625.

Görg, H., Greenaway, D. (2004) Much Ado About Nothing? Do Domestic Firms Really Benefit from Foreign Direct Investment?. World Bank Research Observer. 19. pp. 171-197.

Hardy, J., Pollakova, M., Sass, M. (2011) Impacts of horizontal and vertical foreign investment in business services: the experience of Hungary, Slovakia and the Czech Republic. European Urban and Regional Studies. 18 (4), pp 427-443. DOI: 10.1177/0969776411422618

Hunya G., Geishecker. I. (2005) Employment effects of foreign direct investment in Central and Eastern Europe. The Vienna Institute for International Economic Studies Research Reports. 321. 2005.

Database: Eurostat, Ameco, UNCTAD, GGDC, NBS, World Bank

Iwasaki, I., Tokunaga, M. (2013) Macroeconomic Impacts of FDI in Transition Economies: A Meta-Study. Paper prepared for the 7th MAER-Net Colloquium at the University of Greenwich, London, UK.

Jensen, C. (2006) Foreign Direct Investment and Economic Transition: Panacea or Pain Killer?. Europe-Asia Studies. 58 (6). pp. 881-902. DOI: $10.1080 / 09668130600831084$ 
Johnson, A. (2006) FDI inflows to the Transition Economies in Eastern Europe: Magnitude and Determinants. Working Paper Series in Economics and Institutions of Innovation, 59, Royal Institute of Technology, CESIS Centre of Excellence for Science and Innovation Studies.

Kalotay, K. (2004) The European Flying Geese: New FDI patterns for the Old Continent?. Research in International Business and Finance. 18. pp. 27-49. DOI: 10.1016/j.ribaf.2004.02.006

Kaminski, B., Smarzynska, B. (2001) Integration into global production and distribution networks through FDI: the case of Poland. Post-Communist Economies. 13 (3). pp. 265-288. DOI: 10.1080/14631370120074830

Khawar, M. (2005) Foreign Direct Investment and Economic Growth: A CrossCountry Analysis. Global Eonomy Journal. 5 (1). pp. 1-12. DOI: 10.2202/1524-5861.1057

Kotian, J. (2014) Economic impact of EU membership on Visegrad countries. CEE Special Report. Erste Group Research 2014.

Kornecki, L. (2008) Foreign direct investment and macroeconomic changes in CEE integrating into the global market. Investment Management and Financial Innovations. 5 (4).

Kosová, R. (2010) Do foreign firms crowd out domestic firms? evidence from the Czech republic. The Review of Economics and Statistics. 92 (4). pp. 861-881. DOI: 10.1162/REST_a_00035

Martin, R., Vinkler, A. (2009) Real Convergence in Central, Eastern and SouthEastern Europe. Palgrave Macmillan. ISBN 13:978-0-230-22018-8.

Mišun, J., Tomšík, V. (2002) Dose foreign direct investment crowd in or crowd out domestic investment?. Eastern European Economics. 40 (2). pp. 38-56. Stable URL: http://www.jstor.org/stable/4380291
Nachum, L., Dunning, J. H., Jones, G. G. (2000) UK FDI and the Comparative Advantage of the UK. The World Economy. 23 (5). pp. 701-720. DOI: 10.1111/1467-9701.00297

Moura. R., Forte, R. (2010) The Effects of Foreign Direct Investment on the Host Country Economic Growth - Theory and Empirical Evidence. FEP Working Papers 390, Universidade do Porto, Faculdade de Economia do Porto.

Refslund, B. (2014) Globalisering og international integration af produktion - dansk økonomi i en værdikædeanalyse. Økonomi og Politik. 87 (2). pp. 88-103.

Sass. M., Fifekova, M. (2011) Offshoring and outsourcing business services to central and Eastern Europe: Some empirical and conceptual considerations. European Planning Studies. 19 (9). pp. 1593-1609. DOI: $10.1080 / 09654313.2011 .586196$

Simurina, J. (2006). Creation and transfer technology in CEE countries. Zagreb International Review of Economics and Business. 9 (1). pp. 77-98.

Stehrer et al. (2012) Global value chains and the EU industry. Research Report 383. The Vienna Institute for International Economic Studies.

Yang, B. (2008) FDI and growth: a varying relationship across regions and over time. Applied Economics Letters. 15 (2). pp. 105-108. DOI: $10.1080 / 13504850600749081$

Van Pottelsberghe De La Potterie, B., Lichtenberg, F. (2001) Does Foreign Direct Investment Transfer Technology Across Borders?. The Review of Economics and Statistics. 83 (3). pp. 490-497. DOI: $10.1162 / 00346530152480135$ 